Session 2360

\title{
Being Political in the Global: How engineers accommodate, resist, and experience ambiguity towards globalization
}

\author{
Juan C. Lucena \\ Embry-Riddle Aeronautical University
}

Introduction

Corporations, governments, and the engineers they hire face increasing challenges in the global economy such as mobility of capital and labor, organizational re-structuring across national boundaries, development and implementation of more efficient production and manufacturing practices, among others. Yet we know very little about how engineers understand and experience globalization, and how globalization impacts their education, hiring, daily practices, and designs. In this paper, I outline a theoretical and methodological framework to analyze the impact of globalization on the education, hiring, practices, and designs of engineers in aerospace industries in the US, Europe, and Latin America. Next, I present preliminary ethnographic data that shows how engineers in different US corporate locations view and experience organizational change as one of the features of globalization. Illustrating the differences among engineers' experiences could help upcoming generations of engineering students and professionals understand ways in which they might experience globalization in the workplace. I conclude the paper by making recommendations to engineering educators on educational experiences that might help future engineers deal with the ambiguities that globalization brings upon the workplace.

\section{Literature Review}

Globalization and engineering in the social sciences. There is a significant need for theories and methods to help us understand the relationship between globalization and engineering practice and education. With very few exceptions (e.g., Schott 1994; Worthington 2000), social theorists of globalization have taken engineering for granted, usually as an externality that helps globalization, while scholars of science and technology studies (STS) have neglected globalization as an important dimension in the shaping of technology, including engineering practice and education. The root of the problem might be in scholars' unwillingness to cross disciplinary boundaries. As Ancarani (1995: 653) argued, "there has been relatively little contact to date between scholarship in international relations or political economy and the advances in science and technology studies.... As a result, basic analytic concepts, including 'globalization' and science and technology themselves, have been taken for granted and have not been problematized to a far greater degree than in more traditional areas of S\&T research, such as laboratory studies or controversies."

Furthermore there are significant conceptual and empirical problems with social theories that make implicit a possible role for engineers in globalization. For example, according to Anthony Giddens (1990), expert systems consist of repositories of technical knowledge that can be deployed across a wide range of contexts and establish an element of trust across national and 
cultural contexts. Here, 'trust' allows for the deployment of technical knowledge across local, national, and international contexts. Giddens does not give engineers any special analytical consideration but implied in his theory is a role for engineers as creators and carriers of technical knowledge within these expert systems and their trust for each other, their knowledges, and problem-solving methods in spite of differences in their local, national, and corporate contexts. However, some historical and contemporary accounts of engineering work show that engineers, even within the same corporation or working in the same transnational project, do not trust each other because of tensions, for example, between manufacturing and design (Leslie 1979), and different national origins (Sabbagh 1996). In a survey distributed among engineers in Germany, Spain, France and England in one division of TRW, Grandin and Dehmel (1997) found out that the majority of engineers surveyed felt being judged by their peers on the basis of national stereotypes.

According to David Harvey (1989), in a system of flexible accumulation subcontracted "flexible" workers use their multiple skills to produce products according to rapidly shifting tastes. Globalization also depends on the availability of flexible workers to produce "just-in-time" products according to consumer demands and on the rapid dispersal of those products around the globe. Again, Harvey does not give engineers special conceptual treatment. Furthermore, the desired feature of flexibility in engineers has been taken for granted as something that can be taught in engineering school, particularly if encouraged by corporations hiring engineers and accrediting bodies of engineering education (Boeing 1997; ABET 1998). Flexibility, as a characteristic demanded by globalization, is problematic in engineering education and practice. For example, Downey and Lucena (2001) describe how upper-level engineering students resist to design courses and projects because they have learn to value engineering problem-solving, as taught in traditional engineering science courses, as what counts as engineering knowledge and as one of the defining characteristic of their identity as engineers.

Leslie Sklair (1995) has developed a sociological theory of the global system where the main units of analysis are transnational corporations (TNC), the transnational capitalist class (TCC) (e.g., executives, bureaucrats, capitalist-inspired politicians and professionals, and consumerist elites), and the culture-ideology of consumerism. Although Sklair's theory is useful to help us conceptualize a new global system beyond the nation-state, he does not provide an explanation of how globalization might be experienced differently by different members of the TCC. For Sklair, all members of the TCC, including engineers, "identify their own interests with those of the global capitalist system and, if necessary, against the interest of their 'own' societies as the transnational practices of the system penetrate ever deeper into the areas that most heavily impact their daily lives." (Ibid: 77). However, as Sklair himself admits, "the strength and unity of the TCC are always open to empirical question." (Ibid: 70) The ethnographic data presented in this paper show that, although most engineers might accept the logic of competitiveness as a main feature of globalization, engineers' experiences of the processes and practices brought by globalization vary significantly. Ethnographic data collected for this research project but presented elsewhere shows that engineers acceptance of the logic of competitiveness is even more problematic among engineers coming from different educational traditions or working in different national contexts. 
Globalization and engineering in engineering education. There has been an increasing interest in globalization in the world of engineering education. Some studies, for example, have documented ways in which engineering education, research, and practice are extending beyond national borders, taking a transnational character, and having significant consequences for the U.S. (GUIRR 1992; NSF 1995). Corporate reformers have begun to call for cross-cultural competency in engineering education in light of the challenges of globalization (Boeing 1997; Conditt 1998; Globalization 1995; Honeywell 1998) and the Accreditation Board for Engineering and Technology (ABET), for many years a conservative force in engineering education, has incorporated in its ABET 2000 criteria a call for "broad education necessary to understand the impact of engineering solutions in a global and societal context."

Many important responses to the challenges of globalization are emerging within engineering institutions. The National Science Foundation (NSF) has funded systemic reforms in engineering education under the Engineering Education Coalitions, a multi-million program to develop new curricula aiming at creating $21^{\text {st }}$-century flexible engineers for global competition (NSF 1993; Peden et al 1995). Universities are creating programs to prepare engineers for a global environment such as the Global Engineering Education Exchange (GE3), the Eurotech program at University of Connecticut (Long and Einbeck 1998), the cross-cultural studies of science and technology project at Rensselaer (Anderson et al 1998), the German program at Michigan Tech (Weinman 1995), the International Engineering Program at University of Rhode Island (Grandin and Dehmel 1997), and the WPI projects to globalize engineering education (Hansen 1995; Ma et al 1995).

But key, still open, questions remains for engineering education: how do engineers experience globalization? How could/should engineering education address these experiences?

The theoretical framework and the ethnographic data presented here hopes to contribute to answering these questions by providing educators with new ways to understand how engineers experience globalization.

\section{Theoretical framework}

Some theorists of culture have begun to call for new models of culture. In light of the high mobility of peoples, ideas, customs, and beliefs around the world, they have questioned the usefulness of traditional models of culture where members of a bounded community share a common set of values, beliefs, norms, and behaviors. For example, George Marcus (1998) calls for a new way to talk about the relationship between culture and individuals. "The languages that have been useful in talking about culture and politics in the past don't really seem adequate to this historical moment." (Ibid: p. 67)

Downey $(1998,1999)$ has developed a new concept of cultures where individuals living and working in a particular spatial and temporal location are challenged by a set of dominant images. Dominant images create expectations built over time of what individuals in that particular location are supposed to be, to know, and to do. In this new concept of culture, the image is the same but the experiences of individuals when challenged by a particular image are different. Individuals resist, accommodate, fully accept, and experience ambiguity in different ways when challenged by the same image. Although experiences are different, we can recognize patterns 
among experiences. For example, the image of a global engineer as someone capable of operating and executing different functions across cultural and national borders and dealing with different customers challenge engineers in different ways. Actually, this image has already been proposed by a major engineering employer (Boeing 1997) and endorsed by many engineering societies, as reflected in the main themes of recent professional conferences.

Images materialize in concrete practices and processes when those challenged by the images (executives, managers, engineers) agree to allocate and redirect resources (people, money, assets) to specific ends. For example, the image of globalization as that of competition among corporations for increasing market share and profits while minimizing costs around the world, might materialize in concrete corporate practices such as mergers and the organizational, financial, and technical changes that come with them. The image of the global engineer, for example, has materialized in concrete educational practices such as international education programs for engineers.

\section{Methodological framework}

In order to capture the dominant images of globalization in the world of aerospace engineering and the experiences of engineers as they face these images, I have conducted a two-year multisite ethnography in major aerospace corporations, engineering education prog rams, professional meetings, aerospace shows, etc. My ethnographic approach differs from traditional ethnography which focuses on limited settings for long periods of time. Kunda (1992: 23) claims that "ethnography focuses on limited settings, routines, everyday life, and a strive to understand the 'native point of view' -- what their subjects think they are up to." However, some contemporary anthropologists (Clifford and Marcus 1986; Fox 1991; Marcus 1999) argue that ethnography of the present, particularly if it aims at capturing transnational practices, should not have the pretension of "going native," hence does not need to be so in depth and long at each site. This "multi-sited" approach to ethnography aims at finding connections, parallels, and contrasts among a variety of apparently incommensurate sites (Marcus 1999). Marcus "postmodern ethnography moves out from the single sites and local situations to examine the circulation of cultural meanings, objects, and identities in diffuse time-space." (Ibid: 79) So I am after the creation and diffusion of dominant images of globalization and the contrasts and patterns among the experiences of engineers as they encounter these images.

At each site, my ethnographic research included background research of engineering activities, in-depth interviewing with engineers of different levels, genders, ethic backgrounds, and international experience, participant observation of engineering-related activities including seminars, workshops, courses, and meetings, and archival research. Data has been collected in the form of field notes, recorded interviews, pictures, literature, hand-notes and drawings from engineers, etc. Recorded data has been transcribed into text files. By analyzing these different forms of data, I have revealed dominant images of globalization, practices and processes that materialize from these images, and engineers' experiences of the images, practices, and processes.

Results 
Constructing images of globalization. Images of globalization are constructed, disseminated, and experienced by engineers around the world on an ongoing basis. Vehicles for the construction of these images include fully or partially articulated descriptions of globalization at events like the World Engineers' Congress held in Hanover, Germany, during the summer of 2000, the Global Leadership Program at the Thunderbird American Graduate School for International Management attended mainly by engineers working for companies in the Phoenix Valley, and in-house seminars on globalization sponsored by hi-tech companies. Vehicles for the dissemination of images include emails, corporate webpages, newsletters, and seminars, continuing education programs, and popular magazines and newspapers among aerospace engineers such as Aviation Week and Space Technology, The Wall Street Journal, and The Economist.

Here I describe in detail how an image of globalization was constructed at one of those events. The construction of the image includes several important elements: 1) a setting where the image is constructed and presented; 2) experts who construct the image by using an array of visual, textual, and graphical resources; 3) an audience of engineers from different parts of an organization; 4) attributions of agency to engineers; 5) articulations of cognitive and moral authority about globalization; and 6) re-evaluations of what engineers do in order to convince them to buy into the image.

Setting, audience, and experts. In a mountain town in Northern Arizona, a major aerospace company sponsored a two-day seminar on globalization tailored exclusively for engineers on their way to management positions. This seminar is required for engineers who want to be promoted to management positions. John Greenbay, a former president of the company and the seminar's keynote speaker, developed a comprehensive image of globalization, and the role of the company and its engineers in it. A mechanical engineer by training, John moved through the ranks of this company from salesman to president. As president, John was directly responsible for one of the biggest mergers and one of the largest layoffs in company history. John's trajectory makes him a legitimate voice to speak about globalization to engineers. Now as president emeritus of the company, John addressed a group of approximately 30 engineers using a combination of presentation slides, booklet, and the weight of his former and present title and experience. This seminar is organized by "culture experts" (Kunda 1992) who ensure that the image of globalization is visible beyond John's presentation in booklets, and posters and pictures around the wall of the conference room. Culture experts also provided a constant reminder that this event is part of the company and its message is in line with corporate mission and goals.

Attributing agency to engineers. At the beginning of the presentation, John stated very clear that the company has the goal of growing $10 \%$ each year to attract investors. He compared this goal with the much smaller economic growth in countries abroad to make the point that if the company is to achieve its goal of $10 \%$ then it has to find markets anywhere around the world. "Each one of you will have the responsibility as future managers to find markets to help [this company] meet its growth goal of 10\%." (Greenbay 1999). Explicitly John gave these engineers direct responsibility for the goals of the company. In doing so, John has challenged these engineers to become agents of globalization.

Establishing cognitive authority. John stated that "globalization is a very fuzzy concept." Referencing best-seller books on the subject, he provided a few definitions of globalization such as "a process whereby the world's people are becoming increasingly connected in all parts of 
their lives -cultural, economic, political, technological, environmental..." (Friedman 1999 quoted Greenbay). Then John positioned the multinational corporation (MNC) as the main actor in this process of integration: "the impetus [of globalization is due to] the ever increasing flow of information, money and goods through multinational corporation (MNC's)." (Ibid) John reminded the audience that business practices were very different when he started as an engineer; "the growth and business was right here in the US... [but now] what we are seeing is huge global markets develop...That is why we developed the WTO." (Greenbay 1999) In order to reassure engineers that they will find markets during this new mission of helping the company grow, John explained the growth of foreign investment in China: " [as a country] you have to attract investment or you die." (Ibid) He further explained that competition among nations is for foreign investment by MNCs while competition among MNCs is about finding those opportunities and markets in countries seeking foreign investment.

This seminar took place on the eve of the WTO meetings in Seattle and protesters had already announced that they would try to boycott the meetings. John had to reassure his audience that they will be doing the right thing when helping the company grow and hence aiding globalization.

Establishing moral authority. John gave engineers a sense of national duty. By finding and opening markets abroad, these soon-to-be-managers engineers not only help their company meet its growth goals but help their country fulfill its mission in the world. John said, "the US is the police of the world. We are the boss and set the rules of free-trade. The US dollar is the strongest market [sic] in the world...At this point in history, we have a job to do, we have to be the policeman of the world." (Ibid)

Re-evaluate what is important to you as an engineer. John continued "democratic capitalism is the best wealth generating machine in the world...it is not the best [social] safety net...many people have lost their jobs, lost their houses. We destroy the lowest performing wealth generating business and create new ones." (Ibid) But destruction seems to go against what engineers are good at: inventing and building things. So John had to remind them one more time "investors want growth in stock...[so] what are you going to do to increase the value of stock?" One of the things that companies have to do sometimes to increase the value of stock is to "sell off businesses that are not growing." John acknowledged that this can be frustrating for engineers who want to invent or design something but sometimes they find themselves trying to figure out how to sell a business unit. So according to John, engineers have to learn to ask, "if you [business unit] aren't contributing [to increase stock value], why do I have you around?" (Ibid)

In sum, engineers on their way to management positions were presented not only with an image of globalization but with a clear picture of their role as agents of globalization. First, engineers were given the responsibility to find markets abroad to help the company meet its $10 \%$ growth goal. Second, they are told that through this economic growth abroad MNCs increase the flow of information, money, and goods which in turn increases the interconnectedness among people. This is what John has defined as globalization. Third, they have been reassured that they are doing the right thing. Finally, they have been asked not to think like engineers but like businessmen. 
From images to strategies. So far all US engineers that I have interviewed for this project accept the logic imposed by the dominant image of globalization: in order to compete for investors money, companies have to grow, which means they have to look for markets abroad, and eliminate those parts of the business that are not contributing to the bottom line. None of the engineers in the globalization seminar that I interviewed afterwards expressed problems with John's description of globalization and the engineer's role in it. None of them expressed problems with the logic. Actually, I found engineers at other companies, who have not attended this particular seminar, offering similar descriptions of globalization, and its logic of capitalism, as justification for corporate strategies. However when this logic materializes in specific processes or strategies that a company must put in place to accomplish its competitive aims, engineers experience these differently.

How engineers experience mergers. Most engineers from the aerospace companies that I have researched accept mergers as a logical strategy that companies follow in order to stay competitive in the global markets. Examples of mergers in companies that employ engineers interviewed for this project include Honeywell's merger with Sperry in the mid-1980s, with Allied Signal in 1999, and a failed merger with GE in 2001, and Boeing's merger with McDonnell Douglas in 1998, among others. Ideally, through mergers, companies expand market share, diversify their product line, use resources more efficiently, eliminate bureaucratic redundancies, and hence improve the bottom line. Mergers are important events to understand how engineers experience globalization because of the turbulent impact of mergers on corporate organizational and cultural life, and on engineers' identities. Individuals identity of who they are as engineers is shaped by their perspective: where they come from, what they have done, do now, and want to do as engineers (i.e., their career trajectories), what they know (knowledge acquired through formal education and experience on the job), and what they want in life. As Marcus points out, "distinctive identities are created from turbulence, fragments, intercultural reference, and the localized intensification of global possibilities." (1999: 59) So how do engineers experience mergers? How do mergers challenge engineers' identities and practices?

Mergers bring complex organizational changes to life. For example, engineers at one of the research sites work in a complex three-dimensional work arrangement brought by organizational changes that resulted from the merger between two aerospace giants. A three-dimensional matrix organization of work at one of the research sites, where many of the engineers interviewed for this project work, reveals functional divisions which control budgets, positions, etc, integrated product teams (IPTs) which control engineers' time and assignments, and customers groups which address the specific needs of a customer. This organizational arrangement has challenged engineers' identity, specifically their career trajectories, knowledge and experience, acquired power, and desires.

Organizational changes challenges acquired experience and power. Probably one of the most obvious challenges to engineers from organizational change is when it results in the loss of their political and economic power. Terrell Idaho, a senior mechanical engineer, had no problems with functional divisions because he feels familiar with that structure. Terrell and most of his engineering colleagues had political and economic power under a functional organization. They controlled the budget, the allocation of personnel, and large systems of a military helicopter in which they worked. Under a functional organization, Terrell was in charge of propulsion 
systems, which included fuel systems, flight controls, hydraulics, fluid systems, pneumatic systems, environmental control system, "all the air powered things, the rotor systems and the drive systems." (Idaho 1999). The merger with an aerospace company brought integrated product teams (IPT) to Terrell's company. Terrell now he feels threatened with the new IPT arrangements because, although IPT managers control engineers time and assignments, they do not control the budgets. As program manager, he has lost his power because he no longer controls budgets. When comparing the organization of his old company in the mid-1980s when he was program manager for propulsion systems with the organization under the newly formed company after the merger, Terrell said:

It was a functional organization [in 1985] with a VP of engineering and directors who were responsible for technology and rotor craft design and things of that nature and department managers who were responsible for various disciplines in engineering under those directors, strictly a functional organization and it was organized, I would say, in operations where they conducted the manufacturing activities. But we had matrix organizations through program managers, which really allowed the program manag er to pull in all the resources, all the skills sets that he needed to do his part of the business. So, the program manager was in a much better position because he could control all the budget we can't control the budget yet, we haven't figured out how to do that yet, although we are certainly trying. But in those days when the program manager could own the budget, create the team with all the skill sets he wanted and do the work that he needed to do. So, was it unlike IPT? No, it was not at all unlike IPT. It was actually more efficient because as the program manager you had the budget and control of your destiny, he who controls the money controls everything and the same team, the same players, the same skills, they just had not invented the term integrated product development team. (italics mine) (Ibid)

Organizational change challenges loyalty to others. Mae Arneson is a young engineer accustomed to change in her life. After her mother's suicide, she moved to Florida to attend engineering school. While in school, she got married and divorced. After moving to Hawaii and then to Arizona without having finished an engineering degree, she began to work for an aerospace subcontractor writing technical manuals. Her goal was to join one of the aerospace giants as a full-time engineer but the lack of an engineering degree was getting in the way of her goals. After intense and frustrating quarrels with her manager at the subcontractor, Mae received support from engineers inside an aerospace company to get a full-time job without an engineering degree. Eventually, Mae would complete an engineering degree while working fulltime as an engineer. She developed a sense of loyalty to these engineers for whom she wrote software tools to make their computer-assisted drafting easier. After being assigned to a new job, she struggled between her functional manager, who controls the budget, and her program manager who gives her assignments and writes her evaluations. She wanted to troubleshoot the software that she wrote for the engineers who assisted her in getting into the company. Her functional manager did not want her spending anytime in this but Mae was determined to fulfill her loyalty to the engineers and the software during overtime. Meanwhile her program manager did not mind that Mae fulfilled her previous commitment to her engineering friends. 
Mae: The summer before I started this [current] project, when I first came in as an intern, I had done some work for the crew station, avionics engineers and I had built these systems of GUI's to customize their AUTOCAD because these engineers didn't know how do draw with AUTOCAD. But all of the things they had to draw; I could say "you are always going to draw these things" so I created GUI's so they could always draw them. So it automated their process and it made it really quick. Well an hour or two every week I need to do things to tweak the coding to the GUI's to make improvements if they found a bug or something like that. He [the functional manager] goes through the roof when I spend like two or an hour of my overtime a week working on that for the other department. Again I think it is if because of his schedule, he is like, "if you want to work overtime you work overtime on this [current] project and I am like "no." I started that, I am going to be here to support it and I am going, if they need support, its overtime and he can't force and dictate my overtime.

Juan: Who is going to write your performance evaluation?

Mae: Not him.

Juan: No?

Mae: He may tell my [program] manager what he wants him to put in it but....

Juan: So who's...

Mae: Chip. And Chip [program manager] has no problem with me supporting it and he thinks I should support a tool that I created. Especially since I am willing to do it in over time. (Arneson 2000: 15)

Organizational change creates opportunities to fulfillment. Not all engineers dislike and/or resist organizational change. Bob Schoenhals, a software engineer in his fifties, has come to accept the ever-changing organization of his work because it supports a good life based on the principles of the Church of Latter Day Saints. Bob is employed under the category of engineer at a major aerospace company although he received a degree in liberal arts. His knowledge of foreign languages allows him to do reasonable well writing code in different computer languages. According to Bob, learning a foreign language and learning a computer language are very similar process. His former teaching experience also makes him a good mentor of young en gineers. His commitment to his family and church come first. Bob has no managerial responsibilities or aspirations. He lets the young engineers worry about promotions and overtime.

For Bob, organization of his work is not imposed from within the organization but from without. The helicopter on which Bob works communicates with army tanks and troops on the ground and it is sold to several countries around the world. Different countries have different hardware and software requirements for their helicopters since they have different radio communications within their armies. Regularly countries want to upgrade flight management systems, weapons systems, communication systems and other avionics on the helicopters that they already own. Each new hardware requirement brings a new software requirement. Additionally, the US government demands that Bob's company "sanitizes" the software that they sell to foreign 
customers so they will not have the same capabilities as US Army helicopters. Bob works in coding, testing, sanitizing, and documenting software. He also mentors young software engineers. Bob's engineering activities on any particular month depend on the latest negotiation on the sale of helicopters, software version being released, incoming group of new engineers, or documentation requirements imposed by the US government. His work always changes. Bob never talked, like Terrell or Mae did, of his frustrations with functional and program management structures. Bob moves through the three-dimensional matrix of functions, programs, and customers as required and with relative ease.

Perceived by most engineers as the lowest level of programming, testing is where entry-level engineers are trained to program. By testing software code written by more experienced engineers, newcomers learn to think like other engineers. Bob is willing to be "one of five peons" in testing at the same time that he mentors new engineers in testing. Bob claims that his managers ask him to write documentation for the software because of his minor in English. In addition to his multiple engineering roles, he has to read and answer emails, attend meetings, and meet other expectations of his managers. What keeps Bob motivated to accept multiple roles within a complex three-dimensional matrix organizations are his religious beliefs in the vision of the Church of the Latter Day Saints. He finds his work in multiple software tasks for a helicopter sold to Israel consistent with his belief that the Church of Latter Day Saints is fulfilling God's plan "to gather all the tribes of Israel." In Bob's own words:

Mormons, if you really get them talking candidly, feel that they are mostly in the house of Joseph, that is pretty arrogant, whatever. Because the Jews feel they are from the house of Judah because of their long genealogy and so forth. We feel that we are from people who are scattered and, if you want to know the year it was in the 700BC area, as part of the scattering and lost tribes and so forth. We are being gathered by God because he promised to gathered all the tribes of Israel in the last days. And so that is what I see. So, basically when you say that we are brothers to Judah. Now they [Jews] don't believe it, we are just another Christian wacko group but we do [believe]. So, we feel that we're brothers to Judah but I am very aware of the conflict of interest that could give me. Like Pollard, I don't want to become a spy for Israel; do you see what I am saying? I am very patriotic for America, and once again, my religion would make me having to be honest, so I wouldn't be passing secrets to Israel because I have this feeling. It is just that I have no problems dealing with Israeli's [project] (italics mine) (Schoenhals 2001: 23)

On becoming organizational change. John Faustini comes from a blue-collar background. After receiving a bachelors' degree in industrial engineering, he landed his first job at a major aerospace company in 1982 where he was placed in the rotation program aimed at having entrylevel engineers experience all the different aspects of building an airplane. However, according to John, he got assigned to "chase" engineering orders of parts that came out of engineering design and moved to planning then to purchasing and finally to production. In order to deal with this challenging task, he created a chart that linked the flow of orders between different functional divisions with color-coded dots and lines. John's dots and lines connected functional divisions in the ordering of parts in new ways. In 1982, most aerospace companies, including John's employer, were still organized around clearly defined functional divisions. However, John's dots and lines began to do one of the functions that a matrix organization would do later: 
communicate and organize work across functional divisions. Without realizing the importance of his work, John looked down on his assignment. "I didn't go to [engineering] school to become a dot guy", he says when high-level managers asked him to leave the conference room where he and his colleague were charting the dots and lines. Intrigued by the meetings and bothered by having to leave the room every time that the managers had a meeting, John and his colleague decided to stay in the room one day. Soon into the meeting they realized that the managers have been trying to decipher the dots and lines of their charts and no one had a clue where parts orders went after leaving the engineering division. The VP of industrial engineering was outraged with this situation which John describes as follows:

The VP loses it and [addressing the division managers] says "God damn it, we come in here [conference room] every fucking day, and you tell me you don't have it [part order], and you are telling me you don't have it. This is a bunch of bullshit. We have airplanes to build. We have a responsibility. We have customers...". We [John and his "buddy"] are sitting in the corner going "Holy shit! This is about our dots!" So at first we are beginning to feel good that people actually use our dots, but then we are feeling bad because nobody knows what the hell we are talking about. One day the VP says, "And who the fuck are you?" I'll never forget that, because the guy was just steaming. And I said, “ I know I'm not supposed to speak up, in fact I'm probably not even supposed to be here, but I just touched that engineering order 20 minutes ago, and there's a lady named Mary Anne that sits on the second floor of that building over there, and she's in the area that has the carpeted walls, so I know that it [the order] is in planning, and I know it's there, because I touched it." And the guy here says "Mary Anne who?" I say " I don't remember, black hair-big glasses, but I'm telling you I know its there." He says, "Ok well I'll go check out that one". So they go to the next one, I remember that this guy turns to the two of us, "I suppose you know about this one too." and I said, "Actually yes we do. That one is on the desk of so and so". Just like that he goes, "Where the fuck have you guys been? We argue about these goddamn dots every day. I want you guys going through those charts." Next thing you know we got vice presidents, directors calling us saying "Move the dot, move the dot!" You know I learned from the lesson, no matter what level you are at, these people just want guidance. That's all they wanted, they don't want to argue about this stuff, they just want help." (Faustini 2000: 8)

During his ascent from engineering to management, John began to personally embody the lines and dots that he was drawing as an entry-level engineer. His subsequent job, as manager of industrial engineering, represented the connections that he was establishing among functional divisions. He was now responsible for production processes from beginning to end. Ten years after his first job in this company and under high pressure to deliver airplanes, John negotiated a position that did not exist: liaison between supplier management and production. His job now extended across the functional divisions of procurement and production. According to John, these two never talked to each other:

It was me being the liaison between the production people and the supplier management people. Supplier management never had the interest to work out on the shop floor. They were buyers, professional. The parts were either coming in late or they didn't fit. Since it 
was a new program I was the guy working with the suppliers and supplier management and the production people, kind of piecing it all together as the liaison. (Ibid: 13)

After this position, he became, first, director of major subcontracts and then director of major contracts for one of the most popular large wide-body jet ever built. More recently, he became Coordinator for Global Procurement Strategy for the entire company. John is not only embodying the dots and the lines between functional divisions and companies facilities but he is now embodying the dots and lines between the company and its worldwide suppliers. In sum, from his early days as an entry-level engineer, John understood that management needed guidance in the communication and organization of work across functional divisions. First by visualizing that lines and dots that did not exist and then by embodying them, John became organizational change, transforming the processes and ways in which work was communicated and organized around his company.

\section{Conclusions}

Although images of globalization might be readily accepted by engineers, the organizational changes brought by its logic have significant impact on how engineers experience their work. For example, as we have seen, the movement of budgetary and personnel decision-making, from program to functional managers brought by matrix re-organization, can have a negative impact on engineers' sense of power to get things done and loyalty towards peers. Neither Terrell nor Mae received education to prepare them for the changes in their work that would result from the matrix organization that both had to experience. Strong religious beliefs can minimize the impact of organizational complexity on how engineers experience their work as long as these beliefs are aligned with company's behavior. For example, in Bob's case, the company's sale of helicopters to Israel was in line with his religious vision. However, deep religious beliefs might not be sufficient to deal with the complexities of organizational change. Mae, a very religious person, did not accept the conflict at her job brought by matrix organization. On the other hand, John Faustini's ability to adapt to, and actually become, organizational change could be attributed more to his upbringing than to his formal engineering education.

Some educators have argued for ethics and values education to help engineers cope with the complexities of engineering work. (e.g., Vesilind 1991; Vesilind and Gunn Alastair 1999) Some of these proposals suggest to students that if their values are in conflict with their employer's goal then they should go elsewhere. However, with the logic of globalization spreading widely throughout hi-tech companies as the main justification for new organizational forms, most engineers have no choice but to learn to cope with ever changing organizational change. As other data collected in this project reveals, engineers continuously find conflict with corporate strategies and practices even after changing jobs many times. As long as engineers continue to be employed in hi-tech companies that compete globally, they will encounter conflict wherever they go. Therefore, a more appropriate education to prepare engineers to deal with the challenges brought by globalization might be an liberal-arts-based education that teaches them, first, to recognize and deal with the political dimensions of their work, and, second, to deal with the ambiguity that results from working, sharing, and even valuing perspectives other than one's own. 


\section{Bibliography}

ABET. 1998. Engineering Criteria 2000. ( $3^{\text {rd }}$ edition). Baltimore: ABET.

Ancarani, Vittorio. 1995. Globalizing the World: Science and Technology in International Relations. In Handbook of Science and Technology Studies, edited by Sheila Jasanoff, et.al. Thousand Oaks, CA: Sage.

Anderson, Frances, Hess, David, and Koller, John. 1998. Globalizing Education for Engineering and Science Students. A FIPSE Project Model for "Cross Cultural Studies in Science and Technology."

Arneson, Mae. 2000. Interview by author. Mesa, Arizona, 25 September.

Boeing. 1997. A Manifesto for Global Engineering Education. Summary of the Engineering Futures Conference.

Clifford, James and George Marcus. eds. 1986. Writing Culture: The Poetics and Politics of Ethnography. Berkeley: University of California Press.

Condit, Phillip. 1998. Contributing to U.S. Competitiveness. Main Plenary at the annual meeting of the American Society for Engineering Education, 28 June - 1 July, Convention Center, Seattle, Washington.

Downey, Gary. 1998. The Machine in Me: An Anthropologists Sits Among Computer Engineers. New York: Routledge.

Downey, Gary. 1999. Pedagogy as a cultural project: theory, intervention, and the anthropology of science and technology. Paper presented at the 1999 American Anthropology Association Annual Meeting.

Faustini, John. 2000. Interview by author. Long Beach, California. 14 March.

Friedman, Thomas. 1999. The Lexus and the Olive Tree: Understanding Globalization. New York: Farrar Straus \& Giroux.

Fox, Richard. ed. 1991. Recapturing Anthropology: Working in the Present. Santa Fe, NM: SAR Press.

Giddens, A. 1990. The Consequences of Modernity. Cambridge: Polity.

Grandin, John, and Dehmel, Eric. 1997. Cross-cultural issues in educating engineers for the global workplace. The journal of language for international business, 8 (2): 1-15.

Greenbay, John [pseud.] 1999. Globalization. Audiotapes of seminar by John Greenbay presented corporate workshop on globalization, Prescott, Arizona, November 11, 1999.

Globalization. 1995. Careers and the Engineer, Fall.

Hansen, Peter. 1995. International education and sustainable development: An American experience in Bangkok, Venice, and Guayaquil. The Environmentalist, 15 (4): 252-56.

Harvey, D. 1989. The Condition of Postmodernity. Oxford: Blackwell.

Honeywell. 1998. Globalization: A Phenomenon of the 90s. Phoenix, Arizona: Honeywell Co.

Idaho, Terrell [pseud.]. 1999. Interview by author. Mesa, Arizona, 22 November.

Kunda, Gideon. 1992. Engineering Culture: Control and Commitment in a High-Tech Corporation. Temple University Press: Philadelphia.

Leslie, Stuart. 1979. Charles F. Kettering and the Copper-Cooled Engine. Technology and Culture. 20 (4) 
Long, Richard P. and Kandance Einbeck. 1998. Industry and Eurotech: Partners in International Engineering Education. Paper read at the annual meeting of the American Society for Engineering Education, 28 June - 1 July, Convention Center, Seattle, Washington.

Ma, Y.H., Schachterle, L., and Zeugner, J.F. 1995. WPI projects globalize engineering education in the Pacific Rim. Chemical engineering education, 29 (2): 112-15.

Marcus, George. 1999. Ethnography through Thick and Thin. New York: Princeton University Press.

National Science Foundation. 1993. Engineering Education Coalitions. Washington, D.C.: NSF.

Peden, Irene C., Edward W. Ernst, and John W. Prados. 1995. Systemic Engineering Education Reform: An Action Agenda. Recommendations of a Workshop Convened by the NSF Engineering Directorate. Washington, D.C., 13 July.

Sabbagh, Karl. 1996. $21^{\text {st }}$ Century Jet: the making and marketing of the Boeing 777 . New York: Scribner.

Schoenhals, Bob. 2001. Interview by author. Mesa, Arizona, 26 March.

Schott, Thomas. 1994. "Collaboration in the Invention of Technology: Globalization, Regions, and Centers." Social Science Research, 23: 23-56.

Vesilind, P. A..1991. Views on teaching ethics and morals. Journal of Professional Issues in Engineering Education and Practice. 117(2): 88-95.

Vesilind, P. A. and S. Gunn Alastair. 1999. Spiritual dimensions of environmental ethic for engineers. Journal of Professional Issues in Engineering Education and Practice. 125(3): 83-87.

Weinman, Sigrid. 1995. German for engineers and scientists: Initiatives in international education. Paper presented at the Annual Eastern Michigan University Conference on Languages and Communication for World Business and the Professions.

Worthington, Richard. 2000. Rethinking Globalization : Production, Politics, Actions. New York: Peter Lang Publishing.

\section{JUAN C. LUCENA}

Juan C. Lucena is currently associate professor at Embry-Riddle Aeronautical University in Prescott, Arizona. He received two B.S. degrees in engineering a M.S. in Science and Technology Studies (STS) from Rensselaer. Dr.

Lucena worked with engineering education programs at the NSF before beginning his Ph.D. in STS at Virginia Tech where he began researching and co-authoring (with Gary Downey) a manuscript titled Just Tell Me What the Problem Is: The Making and Re-making of Engineers. He is currently the principal investigator of a NSF-sponsored grant titled Global Engineers: An Ethnography of Globalization in the Education, Hiring Practices and Designs of Engineers in Europe, Latin America, and the U.S. 